\title{
Kettős küldetésben: Mélyülés és integrálódás a Gazdasági és Monetáris Unióban
}

\section{Könyvismertetés \\ Halmai Péter Mélyintegráció - A Gazdasági és Monetáris Unió ökonómiája címü könyvéről ${ }^{1}$}

A Claude Chabrol által rendezett és 1959-ben megjelent Kettős küldetésben (À double tour) címú filmben egy dúsgazdag családot láthatunk, amely az Aix-en-Provence-i impozáns kastélyában él, és látszólag feddhetetlen életvitelt folytat. A család egyetlen leánya beleszeret egy alacsonyabb származású, jött-ment festőmúvészbe, és hozzá akar menni feleségül. A fiú bekerül a családba, és lerántja a leplet a családtagok álszent, hazug világáról, a kifelé jól leplezett búnökről.

A film képkockái jelennek meg a rencenzens előtt, amikor kezébe veszi és beleolvas Halmai Péter Mélyintegráció című könyvébe, és azonnal kérdések sokaságát is megfogalmazza magában. A Gazdasági és Monetáris Unió családtagjai is a Marcoux-családhoz hasonlíthatók, ahol a felszínen minden rendben van, a mélyben viszont zúrzavaros állapotok uralkodnak? A válaszok a könyv elolvasása után meg is érkeznek, és a filmhez hasonlóan egyfajta élesebb kép is összeáll. Az építőkockák összerakása azonban a tárgyalt téma fajsúlyából kiindulva nem hasonlítható egy film megtekintéséhez.

A közgazdász szerző legkevésbé sem szorul terjedelmes bemutatásra, hiszen jól ismert mind a hazai, mind pedig a nemzetközi kutatói/oktatói közösség köreiben. Jelenleg a Nemzeti Közszolgálati Egyetem és a Budapesti Műszaki Egyetem egyetemi tanára. A Magyar Tudományos Akadémia levelező tagja és ugyanezen intézmény Gazdaságtudományi Doktori Minősítő Bizottságának elnöke. Magyarország számára kivételesen értékes tudományos pályafutása során a nemzetközi, illetve az összehasonlító gazdaságtan, a makroökonómia, valamint az agrár-közgazdaságtan területén végzett kiemelkedő tudományos munkája, különösen az európai integráció makroökonómiai összefüggéseinek vizsgálatában elért eredményei elismeréseként 2021-ben Széchenyi-díjat kapott.

Pásztor Szabolcs a Nemzeti Közszolgálati Egyetem Államtudományi és Nemzetközi Tanulmányok Kar habilitált egyetemi docense. E-mail: pasztor.szabolcs@uni-nke.hu

Halmai Péter: A Gazdasági és Monetáris Unió ökonómiája. Budapest, Akadémiai Kiadó, 2020. 
Számos könyv szerzője, és a könyvismertetésben is tárgyalt Mélyintegráció jól illeszkedik korábbi munkái, közöttük a következő kötetek sorába: Krízis és növekedés az Európai Unióban, Tagállami integrációs modellek, Európai gazdasági integráció, a BREXIT forgatókönyvei és hatásai. ${ }^{2}$ Valójában pedig az olvasó egy olyan munkát tart a kezében, amely a korábbiak szintéziseként jelenik meg, és az európai integrációt, a Gazdasági és Monetáris Uniót (GMU) a regionális rendszerek mindmáig egyedi, kivételesen mély és széles formáját veszi górcső alá. 2021 tavaszán a Kereskedelmi Világszervezet (WTO) regionális kereskedelmi integrációkat nyomon követő adatbázisában 342 hatályban lévő kezdeményezést találunk a világgazdaságban. Kis túlzással azt mondhatjuk, hogy minden ország két integrációs kezdeményezésnek is a tagja. A valóság azonban ennél jóval összetettebb. Mélyebb ismeretek birtokában tudhatjuk, hogy csak maroknyi múködik érdemben, és ezek között is éltanuló az Európai Unión belül működő GMU. A GMU - a pénzügyi összefüggéseken túl - a szélesebb integrációs folyamatba is beillesztést igényel. Az integrációelmélet reálgazdasági (kereskedelem- és növekedéselméleti) ${ }^{3}$ összefüggései is megkerülhetetlenek, és olyan gazdaságilag nyitott országban, mint Magyarország a GMU kardinális kérdéseinek áttekintése elemi fontosságú. A kötet a differenciált integráció és a dezintegráció elemzése révén az európai gazdasági integráció átfogó elméletéhez kíván további adalékokat szolgáltatni. A differenciált (nem egyenlő) integráció konstrukciói és lehetőségei a legutóbbi években a nemzetközi szakirodalomban fokozott figyelmet kaptak. A kötet politikai gazdaságtani elemzés keretében, a kölcsönös függés és az átpolitizáltság különböző konstellációi alapján magyarázza a differenciált integráció (illetve differenciált dezintegráció) különféle változatait.

A szerző újszerú értelmezési keretrendszerének kiindulópontja a kereskedelmi integráció. Az olvasó megértheti, hogy mit is jelent ténylegesen a „mély” kereskedelmi integráció. A mélység az európai integráció tekintetében is döntő jelentőségü dimenzió. Egyrészt kifejezi a leginkább előrehaladott regionális integráció elért szintjét (állapotát). Másrészt jelzi a folyamat irányát: a mélyülő, egyre szorosabb integrációt mint fejlődési irányzatot. A mély (regionális) integráció (a kötetben: mélyintegráció) rendszerként, konceptuális keretként történő értelmezése lényeges hozzájárulást ígér az átfogó elméletalkotáshoz.

2 Halmai Péter: Krízis és növekedés. Európai modell, strukturális reformok, Budapest, Akadémiai Kiadó, 2014.; Halmai Péter: Differenciált integráció: gazdasági integrációs modellek. In Halmai Péter (szerk.) Tagállami integrációs modellek. A gazdasági kormányzás új dimenziói az Európai Unióban, Budapest, Ludovika Egyetemi Kiadó, 2019. 67-141.; Halmai Péter: Európai gazdasági integráció. Budapest, Ludovika Egyetemi Kiadó, 2020.; Halmai Péter: Előszó. 9-12.; A brexit gazdaságtana. 83-208.; In Halmai Péter (szerk.): A Brexit forgatókönyvei és hatásai. Budapest, Ludovika Egyetemi Kiadó, 2020.

3 Az európai növekedési modellről és annak fő problémáiról lásd: Péter Halmai - Viktória Vásáry: Growth Crisis in the EU: Challenges and Prospects. Intereconomics: Review of European Economic Policy, 45. (2010), 5. 329-336.; Halmai Péter: Válság és potenciális növekedés az Európai Unióban. Közgazdasági Szemle, 58. (2011), 12. 1059-1081.; Halmai Péter - Vásáry Viktória: Crisis and economic growth in the EU: Medium and long-term trends. Acta Oeconomica, 61. (2011), 4. 465-485.; Elekes Andrea - Halmai Péter: Az új tagállamok növekedési modellje: Kihívások és kilátások. Külgazdaság, 57. (2013), 7-8. 32-66.; Halmai Péter: Krízis és növekedés az Európai Unióban. Európai modell, strukturális reformok. Budapest, Akadémiai Kiadó, 2014. 372.; Halmai Péter: Az európai növekedési potenciál eróziója és válsága. Közgazdasági Szemle, 62. (2015), 4. 379-414.; Halmai Péter: Az európai növekedési modell kifulladása. Közgazdasági Szemle, 65. (2018), 2. 122-160. 
Feltárja a mélyintegráció tartalmi jellemzőit és rendszersajátosságait, a fundamentumként megjelenő gazdasági mechanizmusokat és azok meghatározó tényezőit. Halmai Péter feszes, de ugyanakkor a komplexitást nem nélkülöző mederben tereli az olvasót, amikor rendszerezi a mélyintegráció érdemi tárgyalásához vezető kérdéseket: kereskedelmi liberalizáció, piaci potenciál és skálahatás, tényezőpiaci integráció, kereskedelmi és növekedési hatások rendszerezése. A szerző nem hagyja figyelmen kívül az intraindusztriális kereskedelmet és a valóban mélyebb integrációkra jellemző termelékenységi spillovereket sem. A figyelmes olvasó láthatja a mélyintegráció irányzatait, jellemzőit és következményeit, ráadásul megjelenik az is, hogy milyen mechanizmusok fejtenek ki hatásokat az egyes tagállamokra, amelyek között a dinamikus hatások különösen hangsúlyosak.

A kötet nagy jelentőséget tulajdonít a monetáris integrációnak, és ezért részletesen vizsgálja a sokkok és a sokkabszorpciós mechanizmusok sajátosságait. A szerző nagyon jól látja, és az olvasóját is abba az irányba tereli, hogy az optimális valutaövezetek elméletét széles összefüggésrendszerben érdemes elemezni, amely lehetővé teszi a mélység és a homogenitás alapos körüljárását. Az áttekintés alkalmas arra, hogy felfedezzük a felszín alatti „hazugságokat” és feszültségeket, vagy éppenséggel a széthúzó (divergens) erőket. A könyv nem nélkülözi, mert nem is nélkülözheti a GMU első változatának kritikáját és a rendszerszintű problémák bemutatását, amely ugyancsak alkalmas a felszín alatt lappangó anomáliák feltérképezésére. Kiemelt figyelmet fordít továbbá a konvergencia ${ }^{4}$ és a reziliencia kérdéskörére, és az utóbbit a mélyintegráció fundamentális jelentőségú jellemzőjének tartja. Áttekinti továbbá a legutóbbi válság kezelését és a GMU átfogó reformjának mozgásterét, továbbá rámutat a reformok mozgáscentrumaira (többek között szolidaritás és felelősség, növekvő homogenitás), és felvázolja a reformok kritikus tömegét. ${ }^{5}$

A differenciált integrációt - amelynek közgazdaságtudományi elemzése úttörő jellegű - ugyancsak beilleszti és részletesen feltárja a kötet elemzési keretrendszerében. Végezetül pedig egy egészen látványos felszín alatt lappangó anomália, a dezintegráció

Lásd: Halmai Péter: Felzárkózás és konvergencia az Európai Unióban. Statisztikai Szemle, 87. (2009), 1. 41-62.; Péter Halmai - Viktória Vásáry: Real convergence in the new Member States of the European Union (Shorter and longer term prospects). European Journal of Comparative Economics, 7. (2010), 1. 229-253.; Péter Halmai - Viktória Vásáry: Convergence crisis: economic crisis and convergence in the European Union. International Economics and Economic Policy, 9. (2012), 3-4. 297-322., Halmai Péter: Konvergencia és felzárkózás az euróövezetben. Közgazdasági Szemle, 66. (2019), 6. 687-712.; Halmai Péter: Felzárkózás és konvergencia az európai integráció rendszerében. In Kovács Lajos Péter (szerk.): Közel Európa távol. Budapest, Éghajlat Könyvkiadó, 2019. 189-230.

E témaköröket behatóan vizsgálta - egyebek mellett - a következő múveiben: Halmai Péter: Új geometria: „teljes” gazdasági és monetáris unió? A gazdasági kormányzás új dimenziói az Európai Unióban. Magyar Tudomány, 178. (2017), 1, 6-17.; Halmai Péter: Európai reformok: Többsebességủ Európa? Differenciált gazdasági integráció versus átfogó reform. Európai Tükör, 21 (2018), 3. 21-44.; Halmai Péter: GMU 2.0: felelősség versus szolidaritás? Külgazdaság, 64. (2020), 9-10. 3-34.; Halmai Péter: Középpontban a reziliencia. A Gazdasági és Monetáris Unió mélyítésének egyes tényezői. Pénzügyi Szemle, (2021), 1. 7-31. 
problémakörének analízise történik, amelyet a szerző az integráció mélységének csökkenésével (példaként említve a brexitet) ${ }^{6}$ azonosít.

A könyv betölti küldetését, hiszen alkalmas szélesebb integrációelméleti konklúziók összefoglalására is, és új elemzési keretrendszer bevezetésével mélyintegrációs paradigmát vázol fel. Bemutatja a felszínt és a felszín alatt lappangó feszítő anomáliákat, feszültségeket is. A könyvismertetés utolsó egysége nem ismétli mantraszerűen, hogy a könyv mindenkinek ajánlható, és szélesebb olvasóközönségre tarthat számot. Éppen ellenkezőleg a mélyintegráció tanulmányozása a közgazdaságilag pallérozottabbak esetében lehet támpont, így leginkább azok számára hasznosítható, akik jártasak az elméleti kérdésekben, és meg szeretnék érteni, hogy első körben milyen jellegadó különbségek vannak a sekély és a mélyintegráció között, illetve új elemzési keretrendszerben szeretnék megérteni az utóbbit.

A szerző számos további művében behatóan vizsgálta a brexit problémakörét. Lásd: Halmai Péter: A Brexit lehetséges gazdasági hatásai. Európai Tükör, 21. (2018), 2. 7-32.; Halmai Péter: A dezintegráció gazdaságtana. A brexit esete. Közgazdasági Szemle, 67. (2020), 9. 837-877.; Halmai Péter: A populizmus ára: a Brexit adó. Magyar Tudomány, 181. (2020), 12. 1621-1635. 